This manuscript has been accepted for publication in Creativity and Innovation Management.

Please cite as follows: "Beltagui, A., Darler, W. and Candi, M. (forthcoming). Measuring the deliverable and impressible dimensions of service experience. Creativity and Innovation Management, accepted for publication".

\title{
Measuring the deliverable and impressible dimensions of service experience
}

\author{
Ahmad Beltagui ${ }^{1}$, William Darler ${ }^{2}$, Marina Candi ${ }^{3}$ \\ ${ }^{1}$ University of Wolverhampton Business School, \\ Nursery Street, Wolverhampton, WV1 1AD, United Kingdom \\ a.beltagui@wlv.ac.uk+441902323946. \\ ${ }^{2}$ Horizon Centre for Doctoral Training, University of Nottingham, \\ Triumph Road, Nottingham, NG7 2TU, United Kingdom \\ psxwtd@,nottingham.ac.uk, +441158466920. \\ ${ }^{3}$ The Reykjavik University Center for Research on Innovation and Entrepreneurship, \\ Reykjavik University School of Business, \\ Menntavegur 1, 101 Reykjavik, Iceland. \\ marina@,ru.is, +3545996418.
}

\begin{abstract}
Service innovation has become a priority within the field of innovation management and is increasingly focused on the creation of memorable experiences that result in customer loyalty. Studies of experience design suggest individual service elements to be managed when staging an experience whereas conceptual models in the literature emphasize the holistic way in which an experience is perceived. In short, service experience is greater than the sum of its parts. Therefore, successful innovation management requires the ability to understand and measure the mechanisms by which service innovations impact customers' experiences. Our research addresses this need by identifying dimensions of service experience and developing a tool for their measurement. Using a systematic literature review, rigorous scale development, reduction and validation, we identify six dimensions of the service experience and develop scales to measure each one. This results in a model of service innovation that highlights the levers through which a company's service innovation efforts can result in memorable experiences and ultimately generate service success.
\end{abstract}

\section{Keywords}

Service innovation, Experience, Service experience, Scales, Scale development, Confirmatory factor analysis

\section{Introduction}

The economic importance of service industries has been growing, which has helped fuel an increased interest in services in general and service innovation in particular (Gallouj and Weinstein 1997; Fitzsimmons and Fitzsimmons 2000; Creusen 2011). With the increasingly dominant perspective of value as emergent through (service) interaction between customers and firms (Payne et al., 2008; Chase, 1981) and value-in-use (Raja et al. 2013), the customer's experience (Visser, et al. 2007; Redström 2006) is becoming the focus of service innovation. The work of Zomerdijk and Voss $(2010,2011)$ is important in this regard as it establishes the presence of broadly similar practices among firms that place the experience at the heart of their service innovation efforts. Evidence for the benefits of this emphasis is both 
conceptual and empirical (e.g. Pine and Gilmore, 1998, Candi et al., 2013). What is missing, however, is a reliable method for measuring the impact of service innovation in terms of the service experience. This research contributes by empirically developing a model of the service experience and a measurement tool.

Existing research suggests that businesses should include design of the prerequisites for their desired service experience as an integral part of their service innovation efforts (Pine and Gilmore 1999; Fitzsimmons and Fitzsimmons 2000; Candi et al. 2013) and that this will result in customers' persistent loyalty. These constitute what we refer to as deliverable dimensions of service experience, or the dimensions that a business can control (Grewal et al. 2009). We posit that attention also needs to be given to what we refer to as impressible dimensions of service experience, which are psychological and unique to each individual and each instance of service use. The service experience can be construed as emerging in two ways. Firstly, from reactions to the deliverable dimensions, which are controlled by businesses (Grewal et al. 2009; Berry and Bendapudi 2003) and determine the situation. Secondly, through the emergence of impressible dimensions, representing the intrinsic value created by the service. The impressible dimensions take shape and ultimately occur in the minds of customers as a result of their interaction with the service delivered. As such they are particularly challenging to control. Indeed, because they are more elusive than their deliverable counterparts, mastering the impressible dimensions might be a way to achieve competitive advantage in service innovation.

The deliverable dimensions are part of what can be referred to as experience staging, defined as service development that is intended to create a memorable emotional experience. These dimensions have been the subject of considerable research and are reasonably well understood (e.g. Kotler 1974; Parasuraman et al. 1988; Bitner 1992; Klaus and Maklan 2012). Conversely, the impressible dimensions are poorly understood due to their elusive and subjective nature. Agreement is lacking among conceptual studies and they are only partially captured in disparate empirical studies. The result is repeated calls for measurement of the dimensions that represent a service experience from both the customer and service provider perspectives (Verhoef et al. 2009; Zomerdijk and Voss 2011). This research addresses these calls by distilling and advancing the results of extant research in a theoretically grounded and empirically tested set of scales to measure the dimensions of the service experience that together form a model for service innovation. These measurement scales yield important implications for both theory and practice since they contribute to an understanding of how service innovators can leverage each of the service experience dimensions to improve new service success.

\section{Theoretical Background}

The literature on the topic of experience can be categorized loosely into studies that investigate design issues, or what can be deliberately controlled and delivered in the development process, and studies that examine the experience from the customer perspective. The first category is largely based on case studies or prescriptions derived from practice and identifies some key elements that can contribute to the experience. These include the front-stage and back-stage of the service (Zomerdijk and Voss 2010), the scripts that govern front-stage employees' actions (Tansik and Smith 2000) as well as the intangible messages delivered by employees and service environments (Berry and Bendapudi 2003). These studies also examine the competitive benefits of experience staging (e.g. Candi et al. 2013) and identify the need for coordination of business functions (Kwortnik and Thompson 2009). The second category includes studies that focus on specific variables or aspects perceived by consumers, such as the brand experience (Brakus et al. 2009), the co-creation experience (Verhoef et al. 2009), the customer support experience (Froehle and Roth 2004) or the online search experience (Mathwick and Rigdon 2004). Finally, there are studies that take a broader view and emphasize the necessity for a holistic perspective (e.g. Arnould and Price 1993; Joy and Sherry 2003; Lemke et al. 2011).

Indeed, customers typically retain a memory of an overall experience that represents an aggregation of all the interactions that take place, although there is also emphasis on key moments (Cook et al. 2002; Johnston and Kong 2011), particularly in the case of service failures (Moore 2013). This supports the position that the service experience should be seen as more than the sum of its parts. This raises a challenge for service innovators seeking to identify and manipulate specific elements that influence the service experience, while also recognizing that some factors may be beyond their direct control. 
A notable gap exists in the literature between the holistic definitions offered and the specific firmcontrolled factors to be managed. Holistic models typically examine the emotional journey, or all of the interactions with any aspect of a brand (Brakus et al. 2009) before, during and after service delivery. The danger is that the experience construct becomes too broad and ends up encompassing too much (Lemke et al. 2011), making the actions of service innovators difficult to connect with the resulting service experience. In this research, the service experience is assumed to be individual (Gentile et al. 2007) but also influenced by the situation in which service delivery occurs (Gupta and Vajic 2000). The focus is on the experience during service delivery as opposed to the prior and subsequent stages of the customer's journey.

Three theoretical perspectives are typically used to understand the nature of service experiences, namely bedonic consumption (Chitturi et al., 2008), flow (Mathwick and Rigdon, 2004) and situated action (Gupta and Vajic, 2000. Hedonic consumption (Holbrook and Hirschmann 1982) contrasts with the theory of reasoned action (Fishbein and Ajzen 1975) by arguing that not everything we do is a means to a rational end. Sometimes an experience represents an end in itself by offering intrinsic hedonic value. The concept of flow (Csikszentmihalyi 1977) arose from studies of the intrinsic value inherent in a variety of activities. It is based on the premise that any activity with the right level of intellectual stimulation and challenge can lead to an autotelic or optimal experience (Csikszentmihalyi and Csikszentmihalyi 1992). The theory of situated action adds consideration of the context or situation in which an action occurs (Suchman 1987). It suggests that the experience is not only in the mind, but is connected to an individual's relationship with the environment and the people or things that the environment contains (Gupta and Vajic 2000).

The theory of hedonic consumption suggests that the inherent, emotional value of an experience can be perceived independently of rational judgments about the value of its constituent parts. Flow theory suggests that an individual's experience is determined by their response to an activity, whether it is classed as work or play. Service innovation can influence the nature of the activity itself. Finally, based on the situated action perspective, we argue that a service and its context should be given equal importance. However, the context can be controlled by the service experience management process much more readily than the individual's response to the activities undertaken. Thus, it is important to make a distinction between two sets of service experience dimensions that represent, on one hand, the staged experience that represents the situational context (deliverable dimensions of service experience) and, on the other hand, the perceived experience (impressible dimensions of service experience) relating to an individual and their interaction with a service.

As Zomerdijk and Voss (2011) argue, the lack of accepted metrics for experience typically leads managers to focus on non-experiential metrics of success such as customer satisfaction. If there is value in the service experience that is distinct from satisfaction, loyalty, quality and other measures, then it requires appropriate measurement models. Verhoef et al. (2009) suggest that developing a scale to measure experience is important to enable practitioners to understand and manage it. Furthermore, although Lemke et al. (2011) express some concern over the extent to which specific service contexts could be unique, they too see scale development as an important task for researchers to undertake. Thus, this research is concerned with developing a service innovation model or instrument that brings together the impressible and controllable dimensions of service experience and provides a way to measure and benchmark them.

\section{Research methodology}

Given the wealth of existing conceptual and empirical work in this subject area, a systematic process of rigorous scale development was followed. This process consisted of four stages: 1) identifying existing constructs and measurement items through a systematic literature review; 2) testing the items identified to determine the dimensions represented; 3) systematically developing parsimonious scales to measure each of the dimensions; 4) testing the validity of the scales in two independent empirical contexts. The emphasis in each step was to maintain objectivity through a data driven approach, which meant decisions on what to include or exclude were based primarily on empirical results. Further details of the methodology are included in the next section, which describes the scale development process. 


\section{Scale development}

\section{Identification of potential constructs and measurement items}

A systematic literature review approach (Tranfield et al. 2003; Thorpe et al. 2005) was chosen as it offers an objective, rigorous process to make sense of disparate literatures and bring together numerous complementary and conflicting studies in order to develop a comprehensive model. As Petticrew and Roberts (2006) outline, a systematic literature review should begin with agreement on the research question and development of an appropriate protocol for review, including criteria for inclusion and exclusion, based on this question. The research question was, broadly, to identify the components of service experience and the items used to measure them. To this end, the inclusion criterion was simply that an article included had to identify one or more components of service experience.

The systematic literature review involved the following steps: 1) A list of leading journals in innovation, marketing, consumer research and operations management was selected. The journals included were (in alphabetical order): Creativity and Innovation Management, Harvard Business Review, Journal of Consumer Research, Journal of Marketing, Journal of Marketing Research, Journal of Operations Management, Journal of Product Innovation Management, Journal of Retailing, Journal of Service Research, Marketing Letters, Marketing Science, MIT Sloan Management Review. 2) A list of 30 keywords was generated based on the authors' previous qualitative research on service experience. (The 30 key words were (in alphabetical order): absorption, affect, authenticity, backstage, community, compelling, connection, drama, emotion, engage, entertain, event, experience, feeling, flow, frontstage, hedonic, immersive, interaction, journey, memorable, narrative, participation, sense, service design, social, symbolic, theatre, touchpoints, visual). 3) A search for the 30 keywords was conducted using the ProQuest database, resulting in 7033 articles found. 4) The article titles were scanned to ensure appropriateness of content (Thorpe et al. 2005), for example removing articles having terms such as "From Experience..." in their titles. This resulted in 1455 articles retained. 5) The abstracts of the remaining articles were read and their relevance and suitability determined, resulting in a total of 215 articles retained. 6) Thematic coding of the 215 articles focused on identifying the constructs measured (empirical work) or proposed (conceptual work), resulting in 125 constructs. 7) Assessment of the 125 constructs was carried out by a panel of three independent researchers in the field of innovation, who had not participated in the preceding steps. Each rater selected those constructs he or she believed could be potential dimensions of the service experience. Those that all three experts agreed on were retained, while the others were discussed by the authors, following guidelines for inter-coder agreement (Currie and Lockett 2007). In total, 15 constructs were retained, which are shown in Table 1 along with the sources of items used to measure them. Through a systematic search of articles pertaining to the 15 constructs, a total of 197 measurement items were identified. 
Table 1: Constructs retained following systematic literature review.

\begin{tabular}{|c|c|}
\hline Constructs & Sources for measurement items \\
\hline Absorption & McAlexander et. al., 2002, Wang et al 2007, Ding et.al., 2010 \\
\hline Aesthetics & Mathwick et al 2001, Brakus et al 2009 \\
\hline Affect & $\begin{array}{l}\text { Donovan and Russell, 1982, Unger and Kernan, 1983, Westbrook, 1987, Babin and Darden, 1996, Forman, } \\
\text { 1991, Garg et. al., 2008, Ding et. al., } 2010\end{array}$ \\
\hline Brand Personality & Aaker 1997 \\
\hline Community & McAlexander, 2002, Nambisan and Baron, 2009 \\
\hline Compelling Experience & McAlexander, 2002 \\
\hline Customer Interaction & $\begin{array}{l}\text { Westbrook, 1981, Forman, 1991, Babin and Darden, 1996, Garg et. al. 2008, Nambisan and Baron, 2009, } \\
\text { Dholakia et. al. 2009, Ding et. al., } 2010\end{array}$ \\
\hline Embodiment & Novak et. al. 2000 \\
\hline Environment & Fisher 1974 \\
\hline Participation & $\begin{array}{l}\text { Unger and Kernan, 1983, Forman, 1991, Mathwick et. al., 2002, Dahl and Moreau, 2007, Macginnis et. al., } \\
\text { 2008, Ding et. al., } 2010\end{array}$ \\
\hline Experience Value & Mathwick et. al. 2001 \\
\hline Hedonic/utilitarian & $\begin{array}{l}\text { Unger and Kernan, 1983, Griffin et. al., 2000, Arnold and Reynolds, 2003, Babin et. al., 2004, Dholakia et. } \\
\text { al., } 2009\end{array}$ \\
\hline Symbolism & Laurent and Kapferer, 1985, Allen et. al., 2008 \\
\hline Timing & Unger and Kernan, 1983, Valenzuela et. al., 2010 \\
\hline Usability & Ding et. al., 2010 \\
\hline
\end{tabular}

\section{Identification of dimensions}

Following the systematic literature review, scale development was carried out using surveys to collect data that were subjected to exploratory and confirmatory factor analyses. As in previous studies of experience (e.g. Visser et al. 2007, Brakus et al. 2009) student samples were deemed appropriate for the scale development task up to the point of validation. Given this audience, an ideal, if somewhat unconventional, context for inquiry was libraries. Based on flow theory (Csikszentmihalyi 1977), an experience can arise from work or play, rather than only entertainment settings and, thus, a setting that facilitates hedonic as well as utilitarian goals was sought. Shopping malls and retail environments have previously been used for this purpose (Massara et al. 2013; Babin and Darden 1996; Jones et al. 2006). Retail settings focus on the sale of goods, while the purpose here was to understand an individual's interaction with a service experience. Furthermore, price considerations that relate to extrinsic as opposed to intrinsic motivation, were deliberately avoided (Mathwick et al. 2001) by using the library context.

Libraries provide an ideal context since the students who use them are expected to achieve flow states by becoming intently engaged in their studies there. They also offer other possibilities such as meeting places, particularly when incorporating café or catering facilities. The surveys were distributed to students in a city with two universities, each of which offers multiple libraries, in addition to the presence of municipal libraries.

As a test of face validity, pilot-testing of the survey consisting of all 197 items was conducted. Comments elicited from pilot-testers resulted in changes to the wording of some of the items. The order of items was randomized to avoid any artificial patterns due to relative positioning of items within the survey. Each item referred to "my library" and was expressed as a statement. Agreement was measured using a 5 point Likert scale anchored by Highly Disagree (1) and Highly Agree (5), making a neutral response possible. Participants were provided with instructions asking them to rate each item with reference to the library they used most frequently.

A total of five surveys were conducted (see Table 2), three for scale development and two for scale validation. Data collected from each of the surveys were analysed using Exploratory Factor Analysis (EFA) with the principal factors method and varimax rotation. The initial cut-offs adopted were that only 
items having loadings of at least 0.6 on one factor and loadings of no more than 0.4 on other factors were retained.

Table 2: Surveys conducted for scale development.

\begin{tabular}{|c|c|c|c|c|c|c|c|}
\hline Survey & Respondents & Purpose & $\mathbf{N}$ & Type of analysis & Outcomes of analysis & $\begin{array}{l}\text { Number } \\
\text { of factors } \\
\text { identified }\end{array}$ & $\begin{array}{l}\text { Number } \\
\text { of items } \\
\text { retained }\end{array}$ \\
\hline 1 & $\begin{array}{l}\text { PhD students } \\
\text { who use a } \\
\text { library }\end{array}$ & $\begin{array}{l}\text { Scale } \\
\text { development }\end{array}$ & 98 & $\begin{array}{l}\text { EFA with varimax } \\
\text { rotation }\end{array}$ & $\begin{array}{r}16 \text { factors with eigenvalues } \\
\text { over } 1 \text { accounting for } 99 \% \text { of } \\
\text { the variance }\end{array}$ & 16 & 109 \\
\hline 2 & $\begin{array}{l}\text { Graduate and } \\
\text { undergraduate } \\
\text { students who } \\
\text { use a library }\end{array}$ & $\begin{array}{l}\text { Scale } \\
\text { development }\end{array}$ & 205 & $\begin{array}{l}\text { EFA with varimax } \\
\text { rotation }\end{array}$ & $\begin{array}{r}39 \text { items loading on } 6 \text { factors, } \\
\text { no cross-loadings over } 0.4 \\
\text { All Cronbach alphas }>0.87\end{array}$ & 6 & 39 \\
\hline 3 & $\begin{array}{l}\text { Undergraduate } \\
\text { students who } \\
\text { use a library }\end{array}$ & $\begin{array}{l}\text { Scale } \\
\text { development }\end{array}$ & 781 & $\begin{array}{r}\text { EFA with varimax } \\
\text { rotation followed } \\
\text { by CFA }\end{array}$ & $\begin{array}{r}\text { EFA: } 24 \text { items loading on } 6 \\
\text { factors with loadings of at least } \\
0.7, \text { no large cross-loadings } \\
\text { All Cronbach alphas }>0.85 \\
\text { CFA: } \chi^{2}=461(237 \text { d.f. }) \\
\text { RMSEA }=0.037, \mathrm{GFI}>0.95 \\
\text { CFI }>0.95\end{array}$ & 6 & 24 \\
\hline 4 & $\begin{array}{l}\text { Postgraduate } \\
\text { students who } \\
\text { use a library }\end{array}$ & Scale validation & 228 & CFA & $\begin{array}{r}\chi^{2}=411(237 \text { d.f. }), \text { RMSEA }=0.05 \\
\text { CFI }=0.97\end{array}$ & 6 & 24 \\
\hline 5 & $\begin{array}{l}\text { Customers of } \\
\text { cafés }\end{array}$ & Scale validation & 124 & EFA & $\begin{array}{r}24 \text { items loading on } 6 \text { factors } \\
\text { All Cronbach alphas }>0.8\end{array}$ & 6 & 24 \\
\hline
\end{tabular}

A total of $98 \mathrm{PhD}$ students responded to the first survey. EFA of the survey data yielded 16 factors with eigenvalues over 1, which together accounted for $99 \%$ of the variance. The primary purpose of this first analysis was to reduce the number of survey items in a systematic fashion based on factor loadings as described above, and after reduction 109 items remained.

A total of 205 graduate and undergraduate students responded to the second survey consisting of the 109 retained items. EFA yielded 25 factors with eigenvalues over 1. Examination of the scree plot of the eigenvalues revealed a levelling-off of effect after the $12^{\text {th }}$ factor, which was also the last factor to account for more than $2 \%$ to the total variance. A second EFA was conducted, this time constrained to 12 factors and yielded 54 retained items. A third EFA including only the 54 items yielded 10 factors, each accounting for more than $2 \%$ of the total variance. Further systematic reduction resulted in 39 items loading on 6 factors.

We examined the items loading on each of these six factors and assigned names to the dimensions represented. The six dimensions of service experience identified were, in alphabetical order, absorption, adventure, community, employees, environment, and spontaneity. Of the six dimensions, two (employees and environment) relate to elements of the service situation and represent deliverable dimensions over which the service provider has direct control. The other four (absorption, adventure, community and spontaneity) represent impressible dimensions, often neglected in research on experience. The Cronbach's alphas for all the dimensions were 0.87 or higher, which is more than the generally accepted cut-off of 0.7 (Nunnally and Bernstein 1994). There were no cross-loadings of items of over 0.4, which indicated good discriminant validity.

Table 3 provides definitions of the six dimensions, based on their use in existing literature. A more detailed discussion of each dimension is provided in the next section. 
Table 3: Definitions of service experience dimensions identified through scale development.

\begin{tabular}{|c|c|c|}
\hline Type & Dimension & Definition \\
\hline \multirow{2}{*}{ 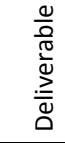 } & Employees & Social interaction between customers and service employees (Mittal and Lassar 1996). \\
\hline & Environment & $\begin{array}{l}\text { The sensory design elements that create awareness of presence within an environment (Joy and Sherry } \\
\text { 2003; Pham et al. 2010). }\end{array}$ \\
\hline \multirow{4}{*}{  } & Absorption & $\begin{array}{l}\text { The feeling of being in a different place (Shin and Shin 2011) and losing track of time and surroundings } \\
\text { due to intense concentration (Csikszentmihalyi 1977; Novak et al. 2000). }\end{array}$ \\
\hline & Adventure & $\begin{array}{l}\text { A state of excitement or arousal due to stimulation or novelty provided by the service (Arnold and } \\
\text { Reynolds 2003; Unger and Kernan 1983). }\end{array}$ \\
\hline & Community & $\begin{array}{l}\text { The sense of belonging to a group through shared interaction with a service (Muniz and O'Guinn 2001; } \\
\text { McAlexander et al. 2002). }\end{array}$ \\
\hline & Spontaneity & Lack of routine, planning or anticipation in the use of a service (Unger and Kernan 1983). \\
\hline
\end{tabular}

\section{Deliverable and Impressible Dimensions of Service Experience}

\section{Impressible Dimensions}

Absorption. A hedonic experience is typically characterized by the intrinsic value it provides a customer (Mathwick, Malhotra and Rigdon 2001). This implies that the experience is not a means to an end but can be viewed as an end in itself. This is more common when the activity is play rather than work, as intrinsic value is considered to be the quintessence of leisure (Unger and Kernan 1983). Work and play, however, are not always clearly distinct (Babin, Darden and Griffin 1994) and there can potentially be an overlap between these two categories, for example when individuals become so absorbed by their work they experience a state of mind referred to as flow (Ghani and Deshpande 1994). This phenomenon was identified by Csikszentmihalyi (1977) who described a number of requirements for flow. These include a match between a task's level of challenge and an individual's level of skill, sufficient control over the task and the requirement for concentration and focus. The result is typically a loss of self-consciousness and transformation of time (Csikszentmihalyi 1997) as the individual becomes absorbed in an activity.

Absorbing experiences have been shown to result in tele-presence and time distortion (Novak et al., 2000) where individuals are so absorbed in an activity that they lose track of the passage of time and become oblivious to their surroundings. In online environments, for example, this translates to a sense of 'being there' (Shin and Shin, 2011) rather than wherever 'here' is, in the same way that a movie or a book can capture the imagination and take the viewer or reader mentally out of their physical situation. When absorbed in this way, time seems to stand still. The resulting intense feelings can result in the formation of habits suggesting loyalty as a potential outcome (Chou and Ting 2010). Customers will typically seek to repeat experiences that absorb them intensely (Celsi, Rose and Leigh 1993), leading to enduring involvement (McGinnis, Gentry and Gao 2008). Service designs elicit different behaviors in individual customers (Cook, Bowen, Chase et al. 2002), making universally positive or negative experiences almost impossible. In this respect, the degree to which an individual is absorbed, or mentally stimulated, by a service is believed to influence the resultant experience (Ding, Hu, Verma et al. 2010). Therefore, it can be expected that a highly absorbing experience that fully captures a customer's attention, should be highly memorable and encourage loyalty.

Adventure. Hedonic activities, from shopping to travel, inspire stimulation and a feeling of being in another world, or in other words a sense of adventure (Arnold and Reynolds, 2003). Recurring themes in literature describing the adventure construct are those of affect and, particularly, arousal. Unger and Kernan (1983) assess arousal in leisure experiences by asking customers if the feel like they are exploring new worlds. Babin and Darden (1996) meanwhile, describe how consumers with hedonic motivations are more likely to be influenced by their emotional state and are therefore more impulsive. This translates to their seeking of thrills, stimulation, and novelty in the experiences they participate in (Arnold and Reynolds 2003; Unger and Kernan 1983). Delivering these aspects of adventure to customers has shown 
to increase the time they are willing to spend, or how compelling an experience is for them (Babin and Darden, 1996; Donovan and Rossiter, 1982).

Community. A key dimension of experience is the relational context (Gupta and Vajic 2000), meaning the relationships and interactions that are developed between customers in connection with the use of a service. In particular, fellow customers and their social impact play an important part in determining the value in use of an experience (Lemke, Clark and Wilson 2011). Zomerdijk and Voss (2010) offer the suggestion that customers act as members of an audience, which implies that their behavior can influence others' experience. An aspect that is often overlooked is how the ties between customers establish them as a community (McAlexander, Schouten and Koenig 2002). That is, they identify with each other on the basis of something they have in common - whether this is where they live, where they work, their choice of leisure or attachment to a service. Membership in a community influences a customer's experience because experiential value can be co-created with fellow customers as well as with the service provider (Tynan and McKechnie 2009). In addition, communities can be formed as a result of a group of people, potentially from differing backgrounds or social standing, sharing an extraordinary experience (McGinnis, Gentry and Gao 2009). On the other hand, a lack of personal contact with others is believed to negatively influence customers' experiences and contribute to feelings of loneliness (Forman and Sriram 1991).

Membership in a community is characterized by three key elements (Muniz and O'Guinn 2001). Firstly, community members share a consciousness of kind, i.e. a feeling that there are others like them, even if they are presently unknown to them. Secondly, they develop common traditions and rituals, constructing a historical context for the offering to which they are attached, and a set of behaviors that unite community members and distinguish them from others. Finally, community members tend to feel a sense of moral obligation towards their fellow members, or towards the community itself, which leads them to help other members often without expectations of a reward. Through sharing knowledge or by socializing, community members typically gain learning, social status, personal status and self-esteem, or more generally in terms of hedonic or emotional benefits (Nambisan and Baron, 2009). For example, even utilitarian activities can provide the social benefits of interacting with other customers (Arnold and Reynolds, 2003). There are many examples of customers using their participation in a community to increase the value of the experience for themselves and others (Prahalad and Ramaswamy, 2004). Yet customers can also act negatively by deliberately being disruptive (Verhoef, Lemon, Parasuraman et al. 2009) to the detriment of other customers' experience. Members of a community can be expected to moderate the behavior of such disruptive individuals due to a sense of moral obligation that comes as part of their community membership (Maffesoli 1996). We therefore expect that the strength of a customer's connection to a community should contribute positively to behavioral outcomes.

Spontaneity. In seeking the determinants of a leisure experience, Unger and Kernan (1983) examine the construct of spontaneity. They argue that whether considering leisure experiences for adults or children's play a key requirement is that the activity should not be routine, planned or anticipated. The timing of a sequence of emotional events is known to strongly influence how it is perceived (Verhoef, Antonides and de Hoog, 2004) and subsequently recalled (Gardial, Clemons, Woodruff et al., 2004). A surprising event typically generates stronger reactions that an identical, but expected one (Valenzuela et al., 2010) meaning that an experience is likely to be more intense when it consists of spontaneous and unexpected events. Additionally, the timing of information provided to customers (Wilcox et al., 2012) and the timing of payment in the purchase process play a part in how an experience is perceived. When making decisions on hedonic rather than utilitarian grounds, the rational thought processes that arise from thinking about the monetary cost conflict with the spontaneity of an experience. There is an argument for paying for experiential offerings ahead of time to avoid the crucial ending of the journey being harmed by the pain of payment (Patrick and Park, 2006). An individual's impulsiveness typically moderates the timing of decision making (Ramanathan and William, 2011) meaning that a more impulsive person will more frequently indulge spontaneously in hedonic offerings and may seek to reduce resulting guilt by immediately following it with a utilitarian task. This can be interpreted as a suggestion that work is what we feel we should be doing, but an experience is more likely to be what people choose spontaneously. Therefore, we surmise that spontaneity is an important dimension of service experience. 


\section{Deliverable Dimensions}

Employees. Social interactions between customers and employees have been identified as being an important part of the service experience (Mittal and Lassar, 1996). These interactions have been shown to contribute substantially to customers' attitudes, intentions and behaviors (Ding, Hu, Verma et al., 2010). There have been many investigations into motives for shopping beyond the purchase of products, including social experience outside of the home (Tauber 1972) and talking to sales personnel (Donovan and Rossiter 1982). Effective customer engagement by employees can be as important as product satisfaction when determining customer loyalty since there is typically repeated contact over a period of time (Westbrook 1981; Tauber 1972). In today's service landscape, interaction with employees does not take place only face-to-face, but through multiple channels including telephone, mail, email and instant messaging.

The social content of employee-customer interaction is referred to as 'personalization' by Mittal and Lassar (1996). Personalization describes the way in which employees relate to customers on a human level and can range from warm and friendly to cold and distant (Mittal and Lassar 1996). Ding, Hu, Verma et al. (2010) assert that through polite, courteous interaction, employees can help customers feel empowered, thus reducing anxiety and increasing perceived control. The interaction between customers and employees has been shown to be an important mediator of customer satisfaction and the personalization of the service encounter greatly influences customers' evaluation of service quality (Mittal and Lassar, 1996). Personalization of a service encounter can have unanticipated psychological benefits. Forman and Sriram (1991) identify services that are visited regularly, such as coffee shops, banks and pharmacies, as providing platforms to initiate social contacts. These social settings can be particularly important for lonely individuals who rely on encounters in the marketplace as their main source of human interaction.

Environment. Retailers invest substantial resources in designing the aesthetics of their stores, catalogues and online services. Kaltcheva and Weitz (2006) explain the different approaches that retailers take to designing their stores. Toys " $\mathrm{R}$ " Us design their stores to be a dream location for children, Barnes \& Noble intend their stores to encourage customers to spend more time shopping, and Home Depot, successfully implement a minimalist, warehouse style design (Kaltcheva and Weitz, 2006). Mathwick, Malhotra and Rigdon (2001) write that visual appeal is driven by the quality of the photography and magazine-like layout in catalogues and the graphic layout, photography and use of color online.

Joy and Sherry (2003) examine the phenomenological nature of experience, focusing on the idea of embodiment (Pham, Goukens, Lehmann et al. 2001). They describe how the body itself and a person's awareness of the physical presence of their body in the environment influence experience. There are conflicting philosophical perspectives of what an experience actually is, with the Kantian view of experience as purely knowledge being compared to Dewey's view of experience as arising from the interaction of human beings with their environment (Brakus, Schmitt and Zarantonello, 2009). These perspectives represent ideas of experience as purely intrinsic or else situated in the interaction with the environment (Gupta and Vajic, 2000). While unconscious cognitive processes take place during any experience (Zaltman, 1997), researchers more commonly highlight the importance of the conscious, sensory interaction between individuals and their environment. Rook (1987) focuses on sensations in the body that compel customers to pay to behave irrationally, for example in highly experiential contexts such as amusement parks. The experience literature also highlights sensory experiences such as skydiving (Celsi, Rose and Leigh, 1993) focusing on the unique sensations inherent in them. Thus, aesthetics, or appealing to the human senses, should be viewed as an important dimension of service experience.

\section{Systematic development of parsimonious scales}

The next stage in the scale development process was to refine and validate parsimonious yet reliable scales for the dimensions, using a final round of data collection. A total of 781 undergraduate students responded to the third survey consisting of the 39 items retained from the previous analysis. EFA yielded the expected six dimensions of service experience. In this stage, we adopted a loading cut off of 0.7 , which is higher than the previously used cut-off of 0.6. This was done in the spirit of the goal of this step, which was scale reduction to arrive at a parsimonious scale. The result was six scales of four items each for a total of 24 retained items. The absence of any large cross-loadings supported discriminant validity. 
The lowest Cronbach's alpha obtained was 0.85 yielding confidence in the reliability of the scale. The reliability of the scales remained high at this stage, despite the reduction in items. This provides a continued level of confidence as Cronbach's alpha values can be expected to decrease with a decreased number of items (Cortina 1993).

Next, we tested the measurement model using Confirmatory Factor Analysis (CFA) with Lisrel 8.8. Goodness of fit was excellent, with a $\chi^{2}$ value of 460.83, with 237 degrees of freedom, which is well within the acceptable range. The Root Mean Square Error of Approximation (RMSEA) was 0.037, which indicates very good fit and other dimensions such as Goodness of Fit Index (GFI) and Comparative Fit Index (CFI) were above 0.95, which suggests excellent model fit (Diamantopolous and Siguaw 2009). We tested convergent validity by checking the significance of all manifest variables' loadings on the latent variables and then by examining the completely standardized loadings. Following Hair et al. (2006), these were deemed acceptable if they were above or close to 0.7 or for two instances of a lower loading, we checked to ensure that the loading was over 0.5 (both 0.59 ) and that their inclusion did not harm the overall model fit. Finally, tests of construct reliability and Average Variance Extracted (AVE) for each dimension provided figures well above the accepted threshold of 0.5 (Dillon and Goldstein 1984). The final scales are shown in Table 2.

Table 4: Scales for measuring the six dimensions of service experience as worded for the library context.

\begin{tabular}{|c|c|c|}
\hline Dimension & Items & Loadings \\
\hline Absorption (based on McAlexander, Schouten and & When I am at my library, I am absorbed intently & 0.76 \\
\hline \multirow[t]{3}{*}{ Koenig 2002 and Ding, Hu, Verma et al. 2010) } & While at my library, I am completely absorbed in what I am doing & 0.81 \\
\hline & When I am at my library, my attention is focused & 0.77 \\
\hline & When I am at my library, I concentrate fully & 0.86 \\
\hline \multirow{4}{*}{$\begin{array}{l}\text { Adventure (based on Babin and Darden 1996, } \\
\text { Griffin, Arnold and Reynolds 2003) }\end{array}$} & While at my library, I feel a sense of adventure & 0.95 \\
\hline & When I go to my library I feel the excitement of the hunt & 0.94 \\
\hline & To me, going to my library is an adventure & 0.94 \\
\hline & My library makes me feel excited & 0.96 \\
\hline Community (based on McAlexander, Schouten and & My library gives me a sense of camaraderie with other library users & 0.76 \\
\hline \multirow[t]{3}{*}{ Koenig 2002, McGinnis, Gentry and Gao 2008) } & I go to my library to enhance my affiliation with the others & 0.79 \\
\hline & I feel a sense of kinship with people in my library & 0.90 \\
\hline & Visiting my library gives me a sense of belonging with others & 0.70 \\
\hline \multirow{4}{*}{$\begin{array}{l}\text { Employees (based on Westbrook 1981, Ding, Hu, } \\
\text { Verma et al. 2010) }\end{array}$} & My library's employees are helpful & 0.73 \\
\hline & My library's employees are friendly & 0.72 \\
\hline & My library's employees are polite & 0.59 \\
\hline & My library's employees are responsive & 0.71 \\
\hline \multirow[t]{4}{*}{ Environment (based on Mathwick and Rigdon 2004) } & My library looks nice & 0.78 \\
\hline & The way everything at my library is displayed is attractive & 0.76 \\
\hline & I like the way my library's environment looks & 0.87 \\
\hline & My library's environment is aesthetically pleasing & 0.88 \\
\hline \multirow[t]{4}{*}{ Spontaneity (based on Unger and Kernan 1983) } & I go to my library without warning or premeditation & 0.87 \\
\hline & Going to my library occurs spontaneously & 0.99 \\
\hline & Going to my library is a "spur of the moment thing" & 0.92 \\
\hline & I do not always decide the day before I will go to my library & 0.59 \\
\hline
\end{tabular}

To test for discriminant validity, we followed the same procedure as Labitzke et al. (2014) by ensuring that the square root of each dimension's AVE was higher than the correlation with any of the other variables. This is shown in Table 5.

Table 5: Correlations with square root of AVE on the diagonal in bold

\begin{tabular}{|c|c|c|c|c|c|c|}
\hline & Community & Environment & Employees & Absorption & Spontaneity & Adventure \\
\hline Community & 0.791 & & & & & \\
\hline Environment & 0.300 & 0.858 & & & & \\
\hline Employees & 0.210 & 0.370 & 0.690 & & & \\
\hline Absorption & 0.250 & 0.310 & 0.330 & 0.801 & & \\
\hline Spontaneity & 0.160 & 0.140 & 0.090 & 0.080 & 0.856 & \\
\hline Adventure & 0.500 & 0.370 & 0.190 & 0.220 & 0.210 & 0.948 \\
\hline
\end{tabular}




\section{Validation in two empirical contexts}

The validity of the survey instrument was tested using two independent samples of respondents. First, the survey was completed by 228 postgraduate students. Once again the model fit achieved using CFA was good, as evidenced by the $\chi^{2}(410.85,237$ degrees of freedom), RMSEA (0.05) and CFI (0.97). As was expected, model fit was a bit poorer for this smaller sample than for the large sample used in the previous step. However, all values were in line with those reported in other research of this nature (e.g. Brettel and Cleven 2011; Rahim, 2014).

Finally, to broaden the scope of our research and improve its generalizability, we conducted a further test of the scales using a non-student sample of 124 customers of cafés including respondents ranging in age from 20 to 70 and equally split between males and females. Respondents were asked to respond for "the café where you spend most time" when answering the survey questions. This sample was not large enough for CFA, but EFA factor loadings and Cronbach's alphas were checked to ensure the same six dimensions were evident. This provides further validation and gives confidence in the robustness of the dimensions. It also ensures the validity of these dimensions for a non-student sample.

\section{Findings}

The four-item scales for the six dimensions of service experience are listed in Table 2. Two of the dimensions - namely employees and environment - refer to deliverable dimensions that can be designed and controlled in the service innovation process. The other four dimensions are impressible dimensions that reflect the effects on customers' perceptions in the mind but are not specifically controllable elements.

Relative to existing research, the novel insight of this work lies largely in the impressible dimensions. Other studies, most notably those of Zomerdijk and Voss (2010 and 2011) highlight sensory design of the environment and the role of employees with respect to the deliverable aspects of service experience and, indeed, these two elements are arguably highly controllable. Alongside these dimensions, this research identifies the uncontrolled impressible dimensions that are influenced by the controllable ones. These impressible dimensions are absorption, adventure, community and spontaneity. The role of the firm may be seen as creating an input by focusing design on the controllable dimensions of service experience, resulting in an output for the customer (Pine and Gilmore 1999; Johnston and Clark 2005), with the intervening processes implicitly seen as something of a black box. Following the data driven approach underlying this research, the impressible dimensions identified help to populate this black box.

\section{Discussion and Conclusions}

This article set out to identify the deliverable and impressible dimensions of service experience and develop a set of scales to measure them, particularly the less understood impressible dimensions. Together the scales form the basis for a proposed model, which identifies the factors that can be controlled and those that are generated within customers' minds. This research offers a survey instrument to measure each dimension, allowing service experience to be measured and improved or benchmarked.

\section{Impressible Dimensions}

Most studies of service experience explicitly refer to hedonic consumption, which suggests the intrinsic motivation of an experiential offering. Some studies have used hedonic consumption as the basis for distinguishing between experiential and more functional service offerings (Batra and Ahtola 1990; Crowley et al. 1992; Zomerdijk and Voss 2010; Beltagui et al. 2012). A more nuanced view can be gained by adding flow theory, bringing our perspective in line with the view that every service results in an experience (Berry et al. 2002; Johnston and Clark 2005). This perspective suggests a positive experience emerges from any activity that can capture the customer's imagination, whether it is pursued for entertainment (e.g. Celsi et al. 1993) or just studying in a library. This research identifies that such experiences can be measured by the dimensions of absorption, adventure, community and spontaneity.

A memorable experience can capture customer attention to the extent that the customer becomes absorbed and loses track of time, or forgets where they are. This is desirable for services that should take the 
customer out of their real life situation into more exotic ones, for example in a theme restaurant. Allied to this is a sense of adventure, giving the customer an intensity of emotion that comes from real or imagined danger. Movies and theatrical performances are often memorable because of the audience's emotional engagement with the actors and the dangers they face and this is captured by the idea of service as theatre. Viewing the customer as an audience member implies that relationships with others are important. Fellow audience members can either have a negative impact on the experience, for example if they make it difficult to become absorbed by the service. Alternatively, a feeling of being part of a community, as when attending a concert or a sporting event can lead to a highly positive experience. And finally, the degree to which the experience is spontaneous, rather than planned in advance, reflects both hedonic decision-making and situated action.

Thus, the underlying theoretical framework of the research suggests service innovation efforts should begin with a deep understanding of customers and how a service can generate appropriate feelings of absorption, adventure and community. Additionally, creative means of encouraging spontaneous decisions should be sought, rather than emphasizing more rational considerations such as value for money (Mathwick et al. 2001). An elegant example is the use of the aroma of coffee, to plant an idea in a customer's head and lead to them to spontaneously visit the nearest café (Klein 2000).

\section{Deliverable Dimensions}

While flow and hedonic consumption appear frequently in the experience literature, situated action is far less prevalent but arguably very important for understanding the link between service innovation and service experience (Gupta and Vajic 2000). The servicescape (Bitner 1992) has long been recognized as a vital part of any service and its design is perhaps the most important consideration highlighted in the experience literature. The other service component that is emphasized in studies of experience is the interaction between customers and employees. Throughout the customer's journey - before, during and after a purchase - the behaviour and appearance of employees and environments offer a wealth of intangible communication between the firm and the customer. The theory of situated action suggests that a customer's response will be greatly influenced by the situation in which an activity takes place. In services, this corresponds to the material context created by sensory design of the environment along with the relational context created by employee interactions. Creating a memorable experience involves investing considerable effort on many interrelated aspects of services (Fitzsimmons and Fitzsimmons 2000). Our findings suggest that the ones customers perceive and can respond to are the employees and environment. These findings reinforce the tradition of emphasis on these dimensions.

\section{Managerial Implications}

Managers typically recognise the importance of creating memorable service experiences. The challenge, however, is to measure the experience and to identify how it can be influenced through service innovation. While innovation can be controlled and managed, the experience is simply a black box in the customer's mind. The results of this research help to open the black box by offering a set of dimensions and a survey instrument for their measurement. Understanding what lies within the black box that transforms the firm controlled inputs into customer perceived outputs is of particular importance to practitioners. It also reinforces the notion that understanding customers should mean understanding the relevant impressible dimensions for the context in addition to the attributes related to the deliverable dimensions. Using measurement of the impressible dimensions as a starting point should help to inform service innovators to create unique, innovative arrangements of the deliverable dimensions that lead to a desired outcome.

\section{Limitations and further research}

The completeness of the identified dimensions is difficult to judge. Rather than uncovering new dimensions, the first problem was to reduce the broad range of constructs found in the literature. Despite the rigour of the research process, it relies on the key constructs being among those conceptually or empirically identified to date and being considered relevant by the respondents to the surveys. The exploratory and confirmatory factor analyses suggest the validity and reliability of the developed scales, but only through further testing can any missing dimensions be identified. Future research could use the 
scales developed here to examine whether the dimensions of service experience hold in other industry contexts and to investigate the interplay between these dimensions.

\section{Acknowledgement}

This work was funded in part by the European Union under the FP7 Marie Curie Industry-Academia Partnerships and Pathways Programme.

\section{References}

Arnold MJ, Reynolds KE (2003) Hedonic shopping motivation. Journal of Retailing 79(2):77-95.

Arnould EJ, Price LL (1993) River Magic: extraordinary experience and the extended service encounter. Journal of Consumer Research 20(2):24-45.

Babin BJ, Darden WR (1996) Good and Bad shopping Vibes: Spending and Patronage Satisfaction. Journal of Business Research 35(3):201-206.

Batra R, Ahtola OT (1990) Measuring the Hedonic and Utilitarian Sources of Consumer Attitudes. Marketing Letters 2(2):159-170.

Beltagui A, Candi M, Riedel JCKH (2012) Design in the experience economy: using emotional design for service innovation. In: Swan S and Zou S (eds) Interdisciplinary approaches to product design, innovation and branding. Emerald, Bingley, pp 111-135.

Berry LL, Bendapudi N (2003) Clueing in customers. Harvard Business Review 81(2):100-106.

Berry LL, Carbone LP, Haeckel SH (2002) Managing the total customer experience. MIT Sloan Management Review 43(3):85-89.

Bitner MJ (1992) Servicescapes: the impact of physical surroundings on customers and employees. Journal of Marketing 56(4):57-71.

Brakus JJ, Schmitt BH, Zarantonello L (2009) Brand experience: what is it? How is it measured? Does it affect loyalty? Journal of Marketing 73(3):52-68.

Brettel M and Cleven NJ (2011) Innovation Culture, Collaboration with External Partners and NPD Performance, Creativity and Innovation Management, 20(4):253-272.

Candi M, Beltagui A, Riedel JCKH (2013) Innovation through Experience Staging: Motives and Outcomes. Journal of Product Innovation Management 30(2):279-297.

Celsi RL, Rose RL, Leigh TW (1993) An Exploration of High-Risk Leisure Consumption through Skydiving. Journal of Consumer Research 20(1):1-23.

Chitturi R, Raghunathan R and Mahajan V (2008), Delight by design: the role of hedonic versus utilitarian benefits, Journal of Marketing, 72 (5), 48-63.

Cook LS, Bowen DE, Chase RB, Dasu S, Stewart DM, Tansik DA (2002) Human issues in service design. Journal of Operations Management 20(2):159-174.

Cortina JM (1993) What is coefficient alpha? An examination of theory and applications. Journal of Applied Psychology 78(1):98-104.

Creusen MEH (2011) Research opportunities related to consumer response to product design. Journal of Product Innovation Management 28:405-408.

Crowley AE, Spangenberg ER, Hughes KR (1992) Measuring the Hedonic and Utilitarian Dimensions of Attitudes toward Product Categories. Marketing Letters 3(3):239-249. 
Csikszentmihalyi M (1992) The flow experience and human psychology. In: Csikszentmihalyi M and Csikszentmihalyi IS Optimal experience: psychological studies of flow in consciousness. Cambridge University Press, New York, pp 15-35.

Csikszentmihalyi M (1977) Beyond Boredom and Anxiety, $2^{\text {nd }}$ ed. Jossey-Bass, San Francisco.

Currie G, Lockett A (2007) A critique of transformational leadership: Moral, professional and contingent dimensions of leadership within public services organizations. Human Relations 60(2):341-370.

Diamantopolous A, Siguaw JA (2009) Introducing LISREL, $6^{\text {th }}$ edition. Sage, London.

Dillon WR, Goldstein M (1984) Multivariate analysis. Methods and applications. Wiley, New York.

Ding DX, Hu PJ, Verma R, Wardell DG (2010) The impact of service system design and flow experience on customer satisfaction in online financial services. Journal of Service Research 13(1):96-110.

Eisenhardt KM (1989) Building theory from case study research. Academy of Management Review 14(4):532-550.

Fishbein M, Ajzen I (1975) Belief, attitude, intention and behavior: an introduction to theory and research. Addison-Wesley, Reading.

Fitzsimmons JA, Fitzsimmons MA (2000) New Service Development: creating memorable experiences. Sage, Thousand Oaks.

Froehle CM, Roth AV (2004) New measurement scales for evaluating perceptions of the technologymediated customer service experience. Journal of Operations Management 22(1):1-21.

Gallouj F, Weinstein O (1997) Innovation in services. Research Policy 26:537-556.

Gentile C, Spiller N, Noci G (2007) How to sustain the customer experience: an overview of experience components that co-create value with the customer. European Management Journal 25(5):395-410.

Grewal D, Levy M, Kumar V (2009) Customer experience management in retailing: an organizing framework. Journal of Retailing 85(1):1-14.

Gupta S, Vajic M (2000) The contextual and dialectical nature of experiences. In: Fitzsimmons JA and Fitzsimmons MJ (Eds.) New service development: creating memorable experiences. Sage, Thousand Oaks, pp 33-51.

Hair JF, Black WC, Babin BJ, Anderson RE, Tatham RL (2006) Multivariate data analysis, $6^{\text {th }}$ edition. Pearson, Upper Saddle River.

Hirschman EC, Holbrook MB (1982) Hedonic consumption: emerging concepts, methods and propositions. Journal of Marketing 46(3):92-101.

Holbrook MB (2006) Consumption experience, customer value, and subjective personal introspection: an illustrative photographic essay. Journal of Business Research 59:714-725.

Holbrook MB, Hirschmann EC (1982) The experiential aspects of consumption: consumer fantasies, feelings and fun. Journal of Consumer Research 9(9):132-140.

Johnston R, Kong X (2011) The customer experience: a road-map for improvement. Managing Service Quality 21(1):5-24.

Johnston R, Clark G (2005) Service operations management, improving service delivery, 2nd ed. PrenticeHall, Harlow.

Jones MA, Reynolds KE, Arnold MJ (2006) Hedonic and utilitarian shopping value: investigating differential effects on retail outcomes. Journal of Business Research 59(9):974-981.

Joy A, Sherry JF (2003) Speaking of art as embodied imagination: a multisensory approach to understanding aesthetic experience. Journal of Consumer Research 30(2):259-282.

Klaus P, Maklan S (2012) EXQ: a multiple-item scale for assessing service experience. Journal of Service Management 23(1):5-33.

Klein N (2000) No Logo: No Space, No Choice, No Jobs. Flamingo, London. 
Kotler P (1974) Atmospherics as a marketing model. Journal of Retailing 49(4):48-64.

Kwortnik RJ, Thompson GM (2009) Unifying service marketing and operations with service experience management. Journal of Service Research 11(4):389-406.

Labitzke G, Svoboda S and Schultz C (2014) The Role of Dedicated Innovation Functions for Innovation Process Control and Performance - An empirical study among hospitals, Creativity and Innovation Management, In Press.

Lemke F, Clark M, Wilson H (2011) Customer experience quality: an exploration in business and consumer contexts using repertory grid technique. Journal of the Academy of Marketing Science 39(6):846-869.

Mathwick C, Rigdon E (2004) Play, flow and the online search experience. Journal of Consumer Research 31(2):324-332.

Mathwick C, Malhotra N, Rigdon E (2001) Experiential value: conceptualization, measurement and application in the catalog and Internet shopping environment. Journal of Retailing 77:39-56.

McAlexander JH, Schouten J, Koening H (2002) Building Brand Community. Journal of Marketing 66(1):38-54.

McGinnis LP, Gentry JW, Gao T (2008) The impact of flow and communitas on enduring involvement in extended service encounters. Journal of Service Research 11(1):74-90.

Mittal B, Lassar WM (1996) The Role of Personalization in Service Encounters. Journal of Retailing 72(1):95-109.

Muniz AM, O'Guinn TC (2001) Brand Community. Journal of Consumer Research 27(3):412-432.

Novak TP, Hoffman DL, Yung Y-F (2000) Measuring the customer experience in online environments: a structural modeling approach. Marketing Science 19(1):22-42.

Nunnally JC, Bernstein IH (1994) Psychometric theory, 3rd ed. McGraw-Hill, New York.

Parasuraman A, Zeithaml VA, Berry LL (1988) SERVQUAL: a multiple-item scale for measuring consumer perception. Journal of Retailing 64(1):12-40.

Payne AF, Storbacka K, Frow P (2008) Managing the co-creation of value. Journal of the Academy of Marketing Science 36(1):83-96.

Petticrew, M and Roberts, H (2006) Systematic reviews in the social sciences: a practical guide, Oxford: Blackwell.

Pham MT, Goukens C, Lehmann DR, Stuart JA (2010) Shaping customer satisfaction through self awareness cues. Journal of Marketing Research 47(October):920-932.

Pine BJ and Gilmore JH (1999) The experience economy: work is theatre and every business a stage. Harvard Business School Press, Boston.

Rahim MA (2014) A structural equations model of leaders' social intelligence and creative performance, Creativtiy and Innovation Management, 23(1):44-56.

Redström J (2006) Towards user design? On the shift from object to user as the subject of design. Design Studies 27:123-139.

Shin D-H, Shin Y-J (2011) Why do people play social network games. Computers in Human Behavior 27(2):852-861.

Schmitt BH (2003) Customer experience management: a revolutionary approach to connecting with your customers, New York, NY: Wiley.

Suchman LA (1987) Plans and situated action: the problem of human machine communication. Cambridge University Press, Cambridge.

Tansik DA, Smith WL (2000) Scripting the service encounter. In: Fitzsimmons JA and Fitzsimmons MJ (Eds.) New service development: creating memorable experiences. Sage, London. 
Thorpe R, Holt R, Macpherson A, Pittaway L (2005) Using knowledge within small and medium-sized firms: A systematic review of the evidence. International Journal of Management Reviews 7(4):257-281.

Tranfield D, Denyer D, Smart P (2003) Towards a methodology for developing evidence-informed management knowledge by means of systematic review. British Journal of Management 14(3):207-222.

Unger LS, Kernan JB (1983) On the meaning of leisure: an investigation of some determinants of the subjective experience. Journal of Consumer Research 9(March):381-392.

Verhoef PC, Lemon KN, Parasuraman A, Roggeveen A, Tsiros M, Schlesinger LA (2009) Customer experience creation: determinants, dynamics and management strategies. Journal of Retailing 85(1):31-41.

Visser, F.S., van der Lugt, R. and Stappers, P.J. (2007) Sharing User Experiences in the Product Innovation Process: Participatory Design Needs Participatory Communication. Creativity and Innovation Management, 16(1): 35 .

Voss C, Roth AV, Chase RB (2008) Experience, service operations strategy, and services as destinations: foundations and exploratory investigation. Production and Operations Management 17(3):247-266.

Westbrook RA (1981) Sources of consumer satisfaction with retail outlets. Journal of Retailing 57(3):6885.

Zomerdijk LG and Voss CA (2010) Service design for experience-centric services. Journal of Service Research 13(1):67-82.

Zomerdijk LG and Voss CA (2011) NSD processes and practices in experiential services. Journal of Product Innovation Management 28(1): 63-80. 